\title{
Mixed grazing trial with suckling cows and dry pregnant ewes
}

\author{
N Grenet 1, J Billant 2 \\ 1/Institut de l'Elevage, Theix, 63122 St-Genès-Champanelle ; 2LEGTA, 52903 Chaumont Cedex 9, France
}

Mixed grazing of sheep and growing cattle improves individual animal performances through the different but complementary valorization of plant cover by the two species (Nolan T, Connoly J, 1989, 40th meeting of EAAP, Dublin, 1-23). On farms where a small flock of ewes lives alongside a herd of beef cows, pasturing them together can be profitable if suckled calves' growth is maintained or improved.

During three successive grazing seasons (from late april to early november), two groups of 15 Limousine cows and their calves (and a bull) were either grazed alone $(C)$ or mixed grazed (M) with pregnant lle de France ewes $(2.25$ ewes/cow) expected to drop in mid october. Two similar 12 ha areas of natural grassland were used. Total stocking rate was 1.72 livestock unit $(\mathrm{LU}) /$ ha for both groups and achieved with additional cows in $\mathrm{C}$ group. The cows had calved for 3 months at turn out and allocated to groups on the basis of parity, calving date, live weight, winter weight loss and sex of suckled calf. The same management was applied each year with each group : 1) rotational grazing on three plots in spring and six in summer with grass from half of the area being harvested for silage around 20 May ; 2) $150 \mathrm{~kg}$ of nitrogen fertilization per ha ; 3 ) creep feeding of calves with $120 \mathrm{~kg}$ concentrate per animal.
The cows, calves and ewes were weighed three times : ten days after turn out ; at the end of June just before the silage area was opened up for grazing and at calf weaning in early October. Gastro-intestine worm larvae were counted on cut grass samples to determine the level of parasite infestation of the grasslands just before calf weaning in autumn.

Because of differences in climate conditions, it was necessary to consider the three years separately. None of the calves, neither in spring nor in summer, benefited from the presence of the ewes. In contrast, the cows gained each year more weight in the mixed group. Weight and body condition of the ewes and subsequently birth weight of the lambs were normal. The number of Ostertagia and Cooperia larvae, although already low in the control (3000 to 4000 per $\mathrm{kg}$ of grass dry matter), decreased by half with mixed grazed area.

In the conditions of this study, the expected increase in pasture quality by mixed grazing benefited the cows alone, perhaps because calves and ewes grazed the same upper strates in the sward. The lower parasite infestation on mixed grazed area was confirmed.

\begin{tabular}{|c|c|c|c|c|c|c|c|}
\hline \multirow{2}{*}{$\begin{array}{l}\text { Year } \\
\text { Group }\end{array}$} & & \multicolumn{2}{|c|}{1} & \multicolumn{2}{|c|}{2} & \multicolumn{2}{|c|}{3} \\
\hline & & C & M & c & $M$ & C & M \\
\hline \multicolumn{8}{|l|}{ ADG calves $(\mathrm{g})$} \\
\hline end april - end june & $\begin{array}{l}M \\
F\end{array}$ & $\begin{array}{l}970^{\mathrm{a}} \\
951^{\mathrm{a}}\end{array}$ & $\begin{array}{l}1230^{\mathrm{b}} \\
935^{\mathrm{a}}\end{array}$ & $\begin{array}{l}1137^{\mathrm{ab}} \\
1131^{\mathrm{b}}\end{array}$ & $\begin{array}{c}1095^{\mathrm{ab}} \\
999^{\mathrm{a}}\end{array}$ & $\begin{array}{l}1246^{\mathrm{b}} \\
1178^{\mathrm{bc}}\end{array}$ & $\begin{array}{l}1177^{\mathrm{b}} \\
1014 \mathrm{ab}\end{array}$ \\
\hline july - weaning & $\begin{array}{l}\mathrm{M} \\
\mathrm{F}\end{array}$ & $\begin{array}{l}1105^{a} \\
934^{a}\end{array}$ & $\begin{array}{l}1023^{a} \\
868^{a}\end{array}$ & $\begin{array}{c}1052^{\mathrm{a}} \\
1007^{\mathrm{abc}}\end{array}$ & $\begin{array}{l}1106^{a} \\
932^{a b c}\end{array}$ & $\begin{array}{l}1000^{a} \\
985^{a c}\end{array}$ & $\begin{array}{l}1070^{a} \\
983^{a c}\end{array}$ \\
\hline Liveweight gain of cows $(\mathrm{kg})$ & & $41 \mathrm{a}$ & $53 a$ & $17^{b}$ & $49 a$ & $37 a$ & $41 \mathrm{a}$ \\
\hline
\end{tabular}

